\title{
Criminal Record and the Principle of Fairness in the Criminal Legislation of the Czech Republic and Poland in the Age of Digitalization
}

\author{
Viacheslav Voronin ${ }^{1, *}$ \\ ${ }^{1}$ Kutafin Moscow State Law University (MSAL), Moscow 125993, Russian Federation \\ *Corresponding author. E-mail: v.w.n@yandex.ru
}

\begin{abstract}
The concept and legal meaning of a criminal record varies significantly in different countries and even in different jurisdictions within a country. In most states of the world, a criminal record is a person's criminal history, which is taken into account when sentencing a newly committed crime. It seems expedient to carry out a survey study of the concept and legal meaning of criminal record in individual Eastern European states and its impact on the implementation of the principle of justice. The subject of the research is the criminal legislation, judicial practice and doctrine of Poland and the Czech Republic. It is supposed to solve the following tasks: to determine the nature and concept of a criminal record; to reveal its general legal significance; to reveal the criminal law value of a criminal record; consider the system of legal restrictions, which involves a criminal record; provide conditions and grounds for cancellation of a criminal record; correlate convictions with other national criminal law institutions. The research results are also significant in that they will bring closer to the global level of research on the problems of criminal records.
\end{abstract}

Keywords: Criminal legislation, digital economy, criminal record, jurisdictions, criminal law, Czech Republic, Poland.

\section{INTRODUCTION}

Conviction is one of the most multifaceted phenomena in law. The concept and legal meaning of a criminal record varies significantly in different countries and even in different jurisdictions within a country. In most states of the world, a criminal record is a person's criminal history, which is taken into account when sentencing a newly committed crime. In some countries, conviction information is limited to enforceable convictions, while in other countries, this information may include information on administrative offenses, charges dropped, prosecutions, cases in which a person has been acquitted. A criminal record may even include information about speeding and drunk driving. The greatest differences in the law of modern states can be traced in the legal, including criminal law, the meaning of a criminal record. Therefore, in Russia, a criminal record serves as a criterion for the individualization of punishment, a criminally-forming sign, a condition for determining the type of correctional institution and an instrument for establishing post-penitentiary control. And in many U.S. states, criminal records only affect the determination of the limits of punishment for a new crime.

It is not difficult to study the legal significance of the criminal record of legal systems popular from a scientific point of view (USA, England, China, France, Germany, Japan, Israel, etc.). A large number of works indexed in international databases are devoted to these issues. At the same time, there are practically no actual studies of the legal nature of criminal convictions in Eastern European countries. In this regard, it seems appropriate to carry out a survey study of the concept and legal meaning of criminal record in individual Eastern European states and its impact on the implementation of the principle of justice. It is supposed to solve the following tasks: to determine the nature and concept of a criminal record; to reveal its general legal significance; to reveal the criminal law value of a criminal record; consider the system of legal restrictions, which involves a criminal record; provide conditions and grounds for cancellation of a criminal record; correlate convictions with other national criminal law institutions. The significance of the research results also lies in the fact that they will allow us to approach the global level of research on the problems of criminal records, and the publication of the results will be able to enrich the world criminal law science with data on the state and prospects of the institution of criminal records in Eastern European states.

\section{CONVICTION IN THE CRIMINAL LAW OF POLAND}

The issues of cancellation and cancellation of convictions in the Criminal Code of Poland are devoted to Art. 110-112. They do not contain the concept of a criminal record and do not describe its consequences, but rather of a procedural nature. Of greater interest is the essential criminal-legal content of a criminal record, which is disclosed in other criminal-legal norms and permeates the 
entire Polish criminal law, as well as is reflected in other legislative acts. Let us dwell, first of all, on the criminallegal meaning of a criminal record, the content of which we have tried to systematize below:

1. If a person previously sentenced to imprisonment for a period of at least 6 months without conditional conviction and deferral of serving the sentence, or convicted under Art. 178a § 4 [1], was again convicted of an intentional crime, then the preferential rule from Part 3 of Art. 58 of the Criminal Code of Poland on the possibility, when imprisonment is imprisoned for no more than 5 years, to immediately replace it with a fine or restraint of liberty (part 4 of article 58 of the Criminal Code of Poland)

2. A person convicted of an intentional crime to imprisonment, which commits, within 5 years after serving at least 6 months of the sentence, a new intentional crime, similar to a crime for which he has already been convicted, the court may impose a penalty for a new crime, up to the upper limit established by law, increased by half (paragraph 1 of article 64 of the Polish Criminal Code)

3. A person previously convicted under the conditions specified above (part 1 of article 64 of the Criminal Code of Poland), who has served at least one year of imprisonment and, within 5 years after serving the last sentence in whole or in part, again commits an intentional crime against life or health, rape, robbery, burglary or other crime in relation to property committed with the use of violence or the threat of its use, the court shall impose a sentence of imprisonment provided for this crime in an amount higher than the lower limit established in the sanction, and may impose and in the amount up to the upper limit set in the sanction, increased by half (paragraph 2 of article 64 of the Criminal Code of Poland);

4. The presence of a conviction for an intentional crime excludes the possibility of a conditional termination of the criminal case (part 1 of Article 66 of the Criminal Code of Poland);

5. The commission of an intentional crime during the probationary period with the conditional termination of the criminal case is a circumstance that leads to the mandatory resumption of criminal prosecution (part 1 of Article 68 of the Criminal Code), and the commission of a crime by negligence is a circumstance that, at its discretion, can lead to the resumption of criminal prosecution (part 2 and 3 of article 68 of the Criminal Code of Poland);

6. In relation to a person guilty of committing a crime specified in Art. 178a $\S 1$ of the Criminal Code of Poland, if he has already been convicted of the indicated act, the court may cancel the conditional imprisonment (paragraph 4 of Article 69 of the fine of the Criminal Code of Poland);
7. If a person commits a similar deliberate crime during the probationary period during the postponement of the serving of imprisonment, then the court is obliged to cancel the suspension and appoint a real serving of imprisonment (paragraph 1 of Article 75 of the Criminal Code);

8. If a person repeatedly commits a reckless act or intentional, for which he is sentenced to a punishment other than imprisonment, then the court has the right to revoke the suspended sentence (paragraphs 2 and 3 of Article 78 of the Criminal Code of Poland);

9. The presence of a conviction for murder is an aggravating circumstance and forms a qualified corpus delicti (paragraph 3 of Article 148 of the Criminal Code of Poland);

10. A conviction for driving under the influence of drugs or for committing crimes specified in Art. 173, 174, 177 or art. $355 \S 2$ of the Criminal Code committed in a state of alcoholic intoxication or drug intoxication is an aggravating circumstance and forms a qualified corpus delicti of driving under the influence of alcohol or under the influence of drugs (paragraph 4 of Article 178a of the Polish Criminal Code);

11. Previously serving a sentence of imprisonment is taken into account in the classification of convicts serving a sentence of imprisonment (paragraph 2 of article 82, paragraph 3 of the Criminal Code of Poland);

12. Conviction for an intentional crime to imprisonment without conditional suspension of his serving leads to the cancellation of parole (part 1 of article 160 of the Criminal Code of Poland);

13. A sentence for a reckless crime or intentional imprisonment with conditional suspension of its execution or other less severe punishment may serve as grounds for canceling parole (paragraph 2 of article 160 of the Criminal Code of Poland).

In addition to the criminal legal consequences, the presence of a criminal record has a wide range of other general legal restrictions that are imposed on a person with a criminal record. Most of these legal restrictions exist in the professional sphere, where a criminal record is an obstacle to engaging in certain activities. As the Supreme Court of Poland noted: "the peculiarity of the absence of a criminal record - as (one of the others) a condition for performing a certain function, holding a position or performing a certain activity - is a kind of statutory criterion that allows one to be active in a certain field. The significance of such a criterion undoubtedly affects, first of all, the area of realization of subjective rights (freedom of economic activity, freedom of choice of occupation - see the Decision of the Constitutional Court of 26.4.1999, K 33/98, OTC 1999, No. 4, 71) and constitutes a restriction of these rights, acceptable because of important public 
interests, the respect of which is necessary in a democratic state governed by the rule of law (Article 31 (3), Article 22, Article 65 (1) of the Polish Constitution) [2]. Thus, in some cases, the law requires the absence of a criminal record for any crime as a condition for occupying certain positions, such as, for example: serving in the police [3], in the Government Security Bureau [4], taking up the post of Inspector General for Personal Data Protection [5] and etc. In other cases, this requirement concerns precisely the absence of a criminal record only for intentional crimes, for example, for the following positions: inspector of financial control [6], teacher [7], academic teacher [8], etc.

\section{CONVICTION IN THE CRIMINAL LAW OF THE CZECH REPUBLIC}

A feature of Czech legislation is the fact that a criminal record, even after serving a sentence and eliminating a criminal record, is registered in the appropriate register, which complicates the integration and resocialization of convicted persons, and also significantly affects the possibility of carrying out professional activities.

In accordance with the Czech Criminal Code, the elimination of a criminal record is possible in two main ways. First, by virtue of the law (ex lege), when the removal of a criminal record does not depend on the will of the person. This happens in the case of full execution of certain types of punishments: community service, prohibition of activities and a fine that is imposed for a negligent act. Also, a criminal record is automatically eliminated in the event of the end of the probationary period under conditional conviction (with supervision) or conditional release from punishment (with supervision). The next case is the entry into force of a court order to release a person from punishment. Also, a criminal record is eliminated regardless of the will of the person in accordance with the rehabilitation decision of the President of the Czech Republic, individually or collectively.

Secondly, there is a procedure for removing a criminal record, which depends on the will of the person (Art. 105,106 of the Czech Criminal Code). Removal of a criminal record is possible under a combination of conditions: the imposed punishment is fully executed, or the person has been pardoned, or the limitation period has expired. After this, it is necessary that the person, for a certain period, which, depending on the punishment imposed, live his usual life:

a) Fifteen years in case of conviction to an exceptional measure of punishment,

b) Ten years in case of imprisonment for more than five years, c) Five years in case of imprisonment for more than one year,

d) Three years in case of imprisonment for up to one year or deportation,

e) One year in case of a sentence of imprisonment, confiscation of property, or punishment in the form of a ban on residence, punishment in the form of a ban on attending sports, cultural and other social events, or a fine for an intentional criminal offense [9].

In exceptional cases, before the expiration of the time period established by law, the convicted person can also apply for the removal of the criminal record, which will be satisfied if he has proved the correction by his behavior.

The elimination of a criminal record annuls all legal consequences arising from the legal fact of the commission of a crime: this also applies to criminal legal consequences (recidivism) and must fully eliminate other general legal consequences. However, in the Czech Republic there is a Law No. 269/1994 Sb. "On the register of convictions" dated 30.12.1994, according to which the register of convictions keeps records of individuals and legal entities found guilty in the framework of criminal proceedings and contains records of all significant facts about this conviction [10]. The data from the register are used for the needs of criminal, civil or administrative proceedings, as well as for confirming the good faith of a person. The register contains data on the presence of a criminal record, conditional conviction, granting a deferral of the execution of punishment, release from punishment. This data is stored for 100 years from the date of establishing any of these legal facts.

\section{CONCLUSION}

In Czech criminal law science, it is noted that the execution of a sentence does not stop the negative impact of a criminal record, since at present one of the conditions for various types of professions or for obtaining various licenses is to establish the good faith of a person. This is not only a condition for admission to public office or the performance of various qualified jobs - nowadays almost every employer requires an extract from the criminal record [11]. Some authors try to draw attention to the excessive frequency of the requirement of good faith (no criminal record), both in the legislation regulating various areas of business, and in hiring practices, when the law itself does not require good faith for a given position [12]. As a result of the calculation, 66 laws, 10 bylaws and 8 provisions on membership in professional associations were identified, which contained the requirements of good faith (no criminal record) as one of the conditions for carrying out any professional activity, for example, the Fisheries Act (Law No. 99/2004 Coll): 
good faith is required when obtaining a fishing permit, as well as for an applicant for a position in the fishing guard, which is confirmed by an extract from the criminal record [13].

The institute for the removal of a criminal record in Czech criminal law is aimed at eliminating all the existing consequences of this condition, it is also aimed at the re-socialization of persons, however, the removal of a criminal record today is not capable of annulling its general social consequences.

\section{ACKNOWLEDGMENTS}

The research is done with financial support from Russian Science Foundation (project № 20-78-00128).

\section{REFERENCES}

[1] Federal Law No. 528-FZ dated 31.12.2014 "Driving while under the influence of alcohol or drugs, during the period of the ban, if the person was previously convicted of the same or similar acts"

[2] Postanowienie SN z dnia 25 października 2007 r., IKZP 33/07, OSNKW 2007, nr 12, poz. 90. https://sip.lex.pl/\#/jurisprudence/520404065?cm=DOCUMENT Accessed 12 Nov 2020

[3] Art. 25 ust.1 ustawy z dnia 6 kwietnia 1990 r. o Policji (tekst jedn.: Dz. U. z 2011 r. Nr 287, poz. 1687 z późn. zm.). https://sip.lex.pl/\#/act/16793593?uni$\mathrm{tId}=\operatorname{art}(25) \mathrm{ust}(1) \& \mathrm{~cm}=$ DOCUMENT Accessed on 12 Nov 2020

[4] Art. 20 ust. 1 ustawy z dnia 16 marca 2001 r. o Biurze Ochrony Rządu (tekst jedn.: Dz. U. z 2004 r. Nr 163, poz. 1712 z późn. zm.) https://sip.lex.pl/\#/act/16894297?uni$\mathrm{tId}=\operatorname{art}(20) \mathrm{ust}(1) \& \mathrm{~cm}=$ DOCUMENT Accessed on 12 Nov 2020

[5] Art. 8 ust. 3 pkt4 ustawy z dnia 29 sierpnia 1997 r. o ochronie danych osobowych (tekst jedn.: Dz. U. z 2002 r. $\mathrm{Nr} 101$, poz. $926 \mathrm{z}$ późn. zm.) https://sip.lex.pl/\#/act/16799013?uni-

$\mathrm{tId}=\operatorname{art}(8) \mathrm{ust}(3) \mathrm{pkt}(4) \& \mathrm{~cm}=\mathrm{DOCUMENT}$ Accessed on 25 Nov 2020

[6] Art. 39 ust.1 pkt2 ustawy z dnia 28 września $1991 \mathrm{r}$. o kontroli skarbowej (tekst jedn.: Dz. U. z 2011 r. Nr 41, $\begin{array}{lllll}\text { poz. } & 214 & \mathrm{Z} & \text { późn. }\end{array}$ https://sip.lex.pl/\#/act/16794403?unitId=art(39)ust(1)pkt(2)\&cm=DOCUMENT__Accessed on 12 Nov 2020

[7] Art. 10 ust.5 pkt4 ustawy z dnia 26 stycznia 1982 r. - Karta Nauczyciela (tekst jedn.: Dz. U. z 2006 r. Nr 97, $\begin{array}{lllll}\text { poz. } & 674 & \mathrm{z} & \text { późn. } & \mathrm{zm} .)\end{array}$ https://sip.lex.pl/\#/act/16790821?unitId=art(10)ust(5)pkt(4)\&cm=DOCUMENT__Accessed on 12 Nov 2020

[8] Art. 109 ust.1 pkt3 ustawy z dnia 27 lipca 2005 r. Prawo o szkolnictwie wyższym (tekst jedn.: Dz. U. z 2012 r. poz. $572 \quad \mathrm{z}$ późn. zm.) https://sip.lex.pl/\#/act/17215286?unitId=art(109)ust(1)pkt(3)\&cm=DOCUMENT_Accessed on 12 Nov 2020

[9] Zákon trestní zákoník. Zákon č. 40/2009 Sb. Částka 11/2009 https://www.zakonyprolidi.cz/cs/200940\#: :text=(2)\%20Na\%20pravomocné\%20odsouzení\%20soudem,i\%20podle\%20práva\%20 České\%20republiky. Accessed on 18 Dec 2020

[10] Zákon č. 269/1994 Sb. Zákon o Rejstř́ku trestů https://www.zakonyprolidi.cz/cs/1994-269?text=odsouzení Accessed on 19 Dec 2020

[11] D. Kučerová (2009) Zahlazení odsouzení. https://is.cuni.cz/webapps/zzp/download/150016401 Accessed on 22 Dec 2020

[12] M. Hubálek, L. Zamboj (2007) Bezúhonnosta rovné zacházení na trhu práce (Legislativní i faktické požadavky bezúhonnostina trhu práce $\mathrm{z}$ pohledu rovného zacházení). Poradna pro občanství/občanská a lidská práva. https://poradna-prava.cz/data/images/Bezuhonnost.pdf_Accessed on 18 Dec 2020

[13] Zákon č. 99/2004 Sb. Zákon o rybníkářství, výkonu rybářského práva, rybářské stráži, ochraně mořských rybolovných zdrojů ao změně některých zákonů (zákon o rybářství) Částka 32/2004, Platnost od 05.03.2004 https://www.zakonyprolidi.cz/cs/2004-99_Accessed on 11 Dec 2020 